\title{
Prognostic Value of Serum Retinoic Acid Receptor Responder Protein 2 (RARRES2) in Chronic Hepatitis C Patients
}

\author{
DALIA R. IBRAHIM, Ph.D.* and PHEBE L. ABDEL-MESSEIH, M.D.** \\ The Department of Biological Applications, Nuclear Research Center* and The Department of Health Radiation Research, \\ National Center for Radiation Research and Technology**, Atomic Energy Authority, Cairo, Egypt
}

\begin{abstract}
Background: Adipocytokines play an important role in the development of metabolic abnormality and fibrogenesis in Chronic Hepatitis $\mathrm{C}$ virus (CHC) infection. The prognosis of $\mathrm{CHC}$ is still ill-defined. Liver biopsy for staging liver injury comprises variable risks. Many biochemical markers that mirror liver injury progression have been suggested.
\end{abstract}

Aim of Study: The aim of this work is to measure the levels of serum Retinoic Acid Receptor Responder Protein 2 (RARRES2) and leptin in normal weight female CHC patients, as well as to study the correlation between these cytokines and the markers of liver damage, to assess the prognosis of chronic hepatitis $\mathrm{C}$.

Subjects and Methods: This study included 100 normal weight (BMI <25) female subjects; 50 patients of $\mathrm{CHC}$, aged

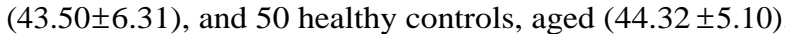
CHC was confirmed by the Polymerase Chain Reaction (PCR). Laboratory investigations included albumin, bilirubin, prothrombin time (the Child Pugh score), fasting glucose, fasting insulin, insulin resistance (HOMA-IR), alanine aminotransferase (ALT), aspartate aminotransferase (AST), AST/ALT and Alkaline Phosphatase (ALP) activities along with serum RARRES2, leptin and alpha-fetoprotein.

Results: Serum RARRES2, leptin, total bilirubin, prothrombin time (INR), ALT and AST activities were significantly higher, and albumin was significantly lower in the normal weight female $\mathrm{CHC}$ patients compared to the control. A significant negative correlation between each of RARRES2 and leptin with albumin; and a significant positive correlation between RARRES2 and INR; indicate that these adipokines increase as liver function worsens.

Conclusion: The serum levels of RARRES2 and leptin may be considered additional non-invasive markers of prognostic significance in $\mathrm{CHC}$ patients.

Key Words: Retinoic Acid Receptor Responder Protein 2 leptin-Chronic hepatitis $C$.

Correspondence to: Dr. Dalia R. Ibrahim, The Department of Biological Applications, Nuclear Research Center, Atomic Energy Authority, Cairo, Egypt

\section{Introduction}

HEPATITIS C Virus (HCV) infection is a widespread disease; it affects millions of people worldwide and is responsible for acute and chronic liver diseases [1]. In Egypt, it is a major public health burden, where it bears the highest prevalence rate in the world [2]. HCV infection increases proinflammatory cytokine secretion, oxidative stress and tissue damage, all of which contribute to progressive fibrosis, cirrhosis, liver failure and cancer [3] . HCV may also contribute to a wide spectrum of metabolic disturbances including impaired glucose metabolism, insulin resistance leading to type 2 diabetes, lipid metabolism abnormalities, obesity, steatosis and cardiovascular events [4-6].

Adipokines which are produced mainly by adipose tissue such as RARRES2, leptin, visfatin and vaspin [7] may influence the development of metabolic abnormalities in $\mathrm{CHC}$ and regulate fibrogenesis and angiogenesis [8]. Adipokines may also contribute to the mechanisms of necroinflammatory progression in chronic viral hepatitis.

Retinoic acid receptor responder protein 2 (RARRES2) (also known as chemerin, TazaroteneInduced Gene 2 Protein or RAR-responsive protein TIG2) [9] is a small secreted protein that was first identified as a ligand for the orphan $\mathrm{G}$ proteincoupled receptor chemokine-like receptor 1 [10] Serum RARRES2 is an adipokine secreted by adipose tissue [11]. It regulates adipogenesis, lipolysis and glucose uptake [12-14]. Besides the adipose tissue, it is also synthesized and secreted by the liver [15]; its receptors expressed in the liver proposed that RARRES2 may have an important impact on the liver physiology and the pathogenesis of CHC [16]. RARRES2 is associated with a pro- 
inflammatory state as it promotes chemotaxis of immature dendritic cells, macrophages and natural killer cells toward the site of inflammation $[\mathbf{1 0 , 1 7 , 1 8 ]}$

Leptin is another adipokine that is expressed mainly in adipose tissue and other organs including the liver [19]. Its expression is regulated by TNF$\alpha$, IL-1 and insulin [20]. Leptin plays an important role in the regulation and metabolism of body fat, promotes insulin resistance, increases intracellular fatty acids in the liver and enhances lipid peroxidation [21-23]. Leptin plays a central role in the regulation of the immune system and inflammatory responses [24]. It induces the release of cytokines such as interferon (INF)- $\gamma$, interleukin (IL)-18, tumor necrosis factor (TNF)- $\alpha$ and transforming growth factor (TGF)- $\beta 1$, and mediates hepatic steatosis and fibrosis during chronic liver injury [22].

It has been observed that serum RARRES2 and leptin levels are affected by gender and adipose tissue as it was reported that RARRES2 and leptin are significantly higher in women than in men and in subcutaneous than in visceral adipose tissue [25] In a previous work by Abdel-Messeih et al. [26], serum RARRES2 (Chemerin) and leptin were significantly increased in normal and overweight male $\mathrm{CHC}$ patients. For this reason, it is considered appropriate to study serum RARRES2 and leptin in normal weight female $\mathrm{CHC}$ patients, to determine the effect of gender and to avoid the effect of overweight since the BMI may influence the serum RARRES2 and leptin levels. The study also focuses on whether RARRES2 and leptin levels can be considered additional non-invasive markers of prognostic significance in $\mathrm{CHC}$ patients.

\section{Subjects and Methods}

\section{1- Patients:}

This study was performed on 100 female subjects stratified into two equal groups. The control group consisted of healthy volunteers with mean age (44.32 \pm 5.10$)$ and BMI $\left(23.32 \pm 1.45 \mathrm{~kg} / \mathrm{m}^{2}\right)$ and the chronic hepatitis $\mathrm{C}$ viral infection group (CHC) with mean age $(43.50 \pm 6.31)$ and BMI $(23.50 \pm 0.78$ $\mathrm{kg} / \mathrm{m}^{2}$ ). They were recruited from Tropical Medicine Department, Kasr Al-Ainy Hospital, in Egypt (from June to November 2018) and categorized as $\mathrm{CHC}$ patients with constantly elevated alanine aminotransferase (ALT) activity for at least 6 months. All patients were normal in weight and normoglycemic.

Exclusion criteria included: Obesity, diabetes mellitus, hepatitis B virus infection, hepatocellular carcinoma and heart or renal failure.
All participants were subjected to full medical history taking and complete clinical examination with special comments on pallor, jaundice, hepatomegaly, ascitis, lower limb oedema, gynaecomastia and malnutrition. Abdominal ultrasonography using convex probe at $3.5 \mathrm{MHZ}$ Toshiba (ECCOCCE) SSA-340 A, was utilized to document the presence of cirrhosis and exclude co-existing hepatic focal lesion.

\section{2- Collection of blood samples and biochemical analysis:}

Blood samples were collected after fasting for 12-14 hours in two test tubes. In one tube, two $\mathrm{ml}$. blood were collected on aqueous trisodium citrate dehydrate to obtain plasma samples for testing INR within 2 hours according to the preferred schedule. Prothrombin time was determined by the Hospitex single channel coagulometer (Hospitex via S. Piero a Quaracchi, 224-50145 FIRENZEITALY). The other test tube was without anticoagulant for separation of serum. After clotting, samples were centrifuged at $2000 \mathrm{xg}$ for 10 minutes The sera were portioned into 3 aliquots, one for immediate analysis of AST, ALT, bilirubin, albumin and fasting glucose by enzymatic colorimetric methods. The other two aliquots were frozen at $-80^{\circ} \mathrm{C}$ and analyzed for quantitative determination of serum RARRES2, leptin, insulin and alphafetoprotein.

RARRES2 and leptin levels were measured using commercially available enzyme-linked immunosorbent assay (ELISA) kits. RARRES2 Quantikine ELISA Kit was supplied by R \& D Systems Inc., and leptin ELISA Kit was supplied by Diagnostic Biochem. Canada Inc. Both insulin and alpha-fetoprotein were assayed by immunoradiometric assay kits (IRMA). Insulin concentration was measured by DIA source INS-IRMA kit, supplied by DIA source immunoassays S.A. (Belgium). Serum alpha-fetoprotein was assayed to exclude hepatocellular carcinoma using Coat-A-Count AFP IRMA kit provided by Diagnostic Products Cooperation (DPC), (157700 west $96 \mathrm{~m}$ street Los Angeles, CA90045-5597). Hepatitis markers were detected by Microparticle Enzyme Immunoassay (MEIA) using the AxSym auto-analyzer provided by Abbott Laboratories Diagnostic Division MaxPlanck-Ring 65205 Germany. These analyses were conducted to exclude co-existent infection with other viruses in patients group and to ensure that the controls are sero-negative for HBV and HCV. The diagnosis of $\mathrm{CHC}$ was confirmed by the presence of serum HCV-RNA assayed by Reverse Transcription Polymerase Chain Reaction (RTPCR) method using Amplicor Roche/Promega v.2 
Diagnostic Test, Branchburg, NJ, USA, and viral load by signal amplification nucleic acid probe assay for the quantitation of human hepatitis $\mathrm{C}$ viral RNA using Bayer Versant HCV RNA 3.0 Assay (bDNA) provided by Bayer Diagnostics, Berkeley, CA, USA in CHC patients.

The Homeostasis Model Assessment-Insulin Resistance index (HOMA-IR) was calculated by the equation: HOMA-IR=Fasting glucose $(\mathrm{mg} / \mathrm{dl})$ multiplied by fasting insulin level (mIU/L) divided by 405 . The cutoff point to define insulin resistance corresponds to HOMA-IR $\geq 3.8$. The non-invasive indicator of liver tissue alterations namely, aspartate aminotransferase/Alanine Aminotransferase Ratio $(\mathrm{AAR})=\mathrm{AST} / \mathrm{ALT}$ was calculated .

\section{3- Compliance and ethical standards:}

An informed consent was obtained from each participant in the study as subject privacy rights must always be observed. This study follows the ethical standards of the institutional and national research committee given in the Declaration of Helsinki 1964, as revised in 2013.

\section{4- Statistical analysis:}

The results were expressed as mean \pm standard deviation. The statistical difference between groups was evaluated using student's $t$-test. Pearson's correlation analysis was conducted to determine the relationships between variables. The Statistical Package for the Social Sciences, Version 15 software was used, and the presentations were performed using Microsoft Excel 2007.

\section{Results}

Table (1) shows that the CHC patients and the control group are both of normal weight (to avoid the effect of obesity on adipokine secretion). No significant differences were detected between the controls and $\mathrm{CHC}$ patients regarding fasting blood glucose, fasting insulin levels and insulin resistance (HOMA-IR). The levels of alpha- fetoprotein showed significant increases in the $\mathrm{CHC}$ patients, yet still below the level of Hepatocellular Carcinoma (HCC). Quantitative PCR analysis confirmed the presence of CHC. Table (2) reveals that serum albumin levels were significantly lower $(p<0.001)$, while total bilirubin and prothrombin time/second (INR) were significantly higher $(p<0.001)$ in CHC patients compared to the controls. Significant increases were recorded for alanine aminotransferase (ALT) $(p<0.001)$ and aspartate aminotransferase (AST) $(p<0.005)$, while AST/ALT was significantly lower $(p<0.005)$ in CHC compared to the controls. Alkaline Phosphatase (ALP) activity showed no significant changes $(p>0.05)$. Serum RARRES2 and leptin showed significant increases $(p<0.0001)$ in $\mathrm{CHC}$ group compared to the control group. Table (3) illustrates the correlation between RARRES2 and leptin with liver function markers in $\mathrm{CHC}$ patients. The correlation analysis statistics revealed a significant positive correlation between RARRES2 and INR ( $r=0.617)$, a significant negative correlation between RARRES2 and albumin $(r=0.720)$ and between leptin and albumin $(r=$ $0.665)$.

Table (1): The Body Mass Index (BMI), glycaemic state, alpha-fetoprotein and quantitative PCR in the CHC patients compared to the controls.

\begin{tabular}{lll}
\hline Parameters & Control $(\mathrm{n}=50)$ & $\mathrm{CHC}(\mathrm{n}=50)$ \\
\hline $\mathrm{BMI}\left(\mathrm{kg} / \mathrm{m}^{2}\right)$ & $23.32 \pm 1.45$ & $23.50 \pm 0.78 \#$ \\
Fasting glucose $(\mathrm{mmol} / \mathrm{L})$ & $5.26 \pm 0.40$ & $5.30 \pm 0.70 \#$ \\
Fasting insulin $(\mathrm{pmol} / \mathrm{L})$ & $70.59 \pm 24.82$ & $84.34 \pm 8.24 \#$ \\
HOMA-IR & $2.28 \pm 0.95$ & $2.69 \pm 1.18 \#$ \\
Alpha-fetoprotein $(\mathrm{g} / \mathrm{l} / \mathrm{h})$ & $4.16 \pm 2.83$ & $169.80 \pm 99.84^{*}$ \\
Quantitative PCR (IU/L) & & $1835.05 \pm 1041.43$
\end{tabular}

The results are presented mean \pm standard deviation.

\#: Not significant $p>0.05$.

*: Highly Significant at $p<0.0001$

Table (2): Liver function markers, serum RARRES2 and leptin levels in the CHC patients compared to the controls.

\begin{tabular}{lll}
\hline Parameters & Control $(\mathrm{n}=50)$ & CHC $(\mathrm{n}=50)$ \\
\hline Albumin (mmol/L) & $0.68 \pm 0.09$ & $0.54 \pm 0.25 *$ \\
Total bilirubin ( $\mathbf{m}$ //L) & $13.54 \pm 4.21$ & $20.31 \pm 5.85^{*}$ \\
Prothrombin time/second (INR) & $1.13 \pm 0.07$ & $1.37 \pm 0.19 *$ \\
Alanine amino transferase (ALT) (IU/L) & $17.90 \pm 4.08$ & $80.30 \pm 44.18 *$ \\
Aspartate amino transferase (AST) (IU/L) & $21.61 \pm 7.43$ & $67.84 \pm 52.68 *$ \\
AST/ALT & $1.33 \pm 0.49$ & $0.91 \pm 0.29 *$ \\
Alkaline phosphatase (ALP) (IU/L) & $94.64 \pm 54.61$ & $107.54 \pm 50.99 \#$ \\
Leptin (ng/ml) & $3.98 \pm 0.62$ & $7.51 \pm 2.68 *$ \\
RARRES2 (ng/ml) & $93.95 \pm 23.66$ & $254.13 \pm 91.21 *$ \\
\hline
\end{tabular}

The results are presented mean \pm standard deviation.

\#: Not significant $p>0.05$.

$*$ : Highly significant at $p<0.01$. 
Table (3): Correlation between RARRES2 and leptin with liver function markers in the CHC patients.

\begin{tabular}{lllllll}
\hline Parameters & \multicolumn{1}{c}{ Albumin } & INR & ALT & AST & ALP & Bilirubin \\
\hline RARRES2 in CHC & $r=-0.720, p<0.001$ & $r=0.617, p<0.001$ & NS & NS & NS & NS \\
Leptin in CHC & $r=-0.665, p<0.001$ & NS & NS & NS & NS & NS \\
\hline Values of correlation coefficient $(r)$ are significant at $p<0.001$. & & & &
\end{tabular}

\section{Discussion}

Adipocytokines have an important impact on the development of metabolic abnormality and fibrogenesis in $\mathrm{CHC}$ [27]. $\mathrm{HCV}$ induces hepatic insulin resistance, immune mediated extrahepatic diabetogenic effect and steatosis [28]. HCV genotype 1 induces insulin resistance [29] as it interferes with insulin signaling on hepatocytes [30]. It also contributes to steatosis, fibrosis progression and resistance to interferon and ribavirin treatment [31] HOMA-IR and immunoreactive insulin levels positively correlated with the progression of liver fibrosis among the non-diabetic patients with chronic hepatitis $C$ virus infection [32]. In humans, high serum levels of RARRES2 were conveyed with impaired glucose tolerance and both types of diabetes (insulin dependent and non-insulin dependent diabetes) [33].

Serum AFP is an important predictive marker for Hepatocellular Carcinoma (HCC) and it is of a high value in its diagnosis and follow-up [34]. It is also elevated in acute and chronic hepatitis [35, 36]. AFP was performed in the present study with abdominal ultrasonography to exclude co-existent HCC. The level of AFP was higher in the CHC patients compared to the control group, however its level was less than the specificity level for the determination of $\mathrm{HCC}$ in the $\mathrm{CHC}$ patients [37].

Liver biopsy is a gold standard method for assessment of liver damage, however it is an invasive method. Identification of non-invasive markers to evaluate the progression of liver injury has been strongly recommended, mainly in HCV. Child Pugh score, alanine aminotransferase and bilirubin were evaluated as non-invasive markers [38]. Also the albumin-bilirubin (ALBI) score [39] and aspartate Aminotransferase-to-Platelet Ratio Index (APRI) indicate liver fibrosis staging in patients with $\mathrm{HCV}$ infection [40]. The novel adipokines, RARRES2 and leptin were measured as non-invasive markers and the presence of correlations between the markers of liver prognosis and these novel adipokines were studied.

Previous studies reported that liver injury may be associated with circulating RARRES2 [41-43] and the liver contributes to the serum levels [44] In the present study, serum RARRES2 levels significantly increase in the CHC patients, which is in agreement with the findings of Kukla et al. [8], that was surprisingly negatively correlated with necro-inflammation proved by liver biopsy [8], despite the documented role of RARRES2 in inflammation.

In this work, only female subjects were investigated to study the impact of gender on adipokines levels in the CHC patients, as it was reported by some studies that gender may affect the serum RARRES2 levels. Many studies observed that the levels of serum RARRES2 (chemerin) were significantly higher in females compared to males with metabolic disturbances as type 2 diabetes mellitus [45-47] . Ibrahim et al. [48] reported that serum RARRES2 significantly increased in overweight and obese individuals compared to normal weight, which agreed with some previous studies $[49,50]$ In a previous work by Abdel-Messeih et al. [26], serum RARRES2 (Chemerin) and leptin significantly increased in normal and overweight male $\mathrm{CHC}$ patients. The idea whether the increase of chemerin and leptin in Abdel-Messeih et al. work was due to overweight or $\mathrm{CHC}$ infection is illdefined. Therefore, in this work, only normal weight CHC patients were studied to avoid the influence of excess adipose tissue on adipokines levels.

Serum leptin concentrations were significantly higher in CHC patients compared to the controls. These results are in consistence with the findings of Sell et al. and Tiftikci et al. [41,51]. This effect could be attributed to the role of leptin in stimulating fibrogenesis [52]. Mousa et al. [53] reported that serum leptin could be considered a novel predictor of early liver fibrosis in chronic hepatitis B virus infection. Leptin simulates to a great extent RARRES 2 , as their concentrations are highly correlated with body fat storage and show sexual dimorphism. Serum leptin levels were higher in overweight and obese subjects compared to normal weight individuals [54,55]. Moreover, its levels were also significantly higher in females compared to males, regardless of BMI [54,56,57]. 
The gender differences in serum RARRES2 and leptin concentrations can be attributed to the higher relative amount of adipose tissue in females, regardless of BMI compared to males [57]. Sexual hormones such as estrogen and testosterone may also be involved in their regulations $[\mathbf{5 8 , 5 9}]$

The prothrombin time value is related to hepatic synthesis of proteins involved in the clotting process; that is why it is widely used as a marker of liver function. In the present study, the prothrombin time (INR) was significantly higher in the $\mathrm{CHC}$ patients compared to the normal control and there was a significant positive correlation between serum RARRES2 and the prothrombin time (INR) $(r=0.617)$. Albumin is a protein produced only by the liver and circulates in the blood. A low serum albumin concentration indicates poor liver function and significant liver damage in the $\mathrm{CHC}$ patients. Albumin was significantly lower in the $\mathrm{CHC}$ patients compared to the normal control and there was a significant negative correlation between both serum RARRES2 $(r=-0.720)$ and leptin $(r=-0.665)$ with albumin. These findings revealed that significant increases in the serum levels of RARRES2 and leptin occur as liver functions deteriorate, as was confirmed by the significant decrease of albumin and increase of INR.

\section{Conclusion:}

The serum levels of RARRES2 and leptin may be considered novel non-invasive markers for the prognosis of $\mathrm{CHC}$.

\section{References}

1- MOHAMED A.A., LOUTFY S.A., CRAIK J.D., HASHEM A.M. and SIA I.: Chronic hepatitis C genotype4 infection: Role of insulin resistance in hepatocellular carcinoma. Virol. J., 8: 496, 2011.

2- GOMAA A., ALLAM N., ELSHARKWAY A., ELKASSAS M. and WAKED I.: Hepatitis C infection in Egypt: Prevalence, impact and management strategies. Hepatic Medicine: Evidence and Reaearch, 9: 17-25, 2017.

3- LOGUERCIO C. and FEDERICO A.: Oxidative stress in viral and alcoholic hepatitis. Free Radic. Biol. Med., 34: 1-10, 2003.

4- CHANG M.L.: Metabolic alterations and hepatitis C: From bench to bedside. World J. Gastroenterol., 22: 146176, 2016.

5- HU J.H., CHEN M.Y., YEH C.T., LIN H.S., LIN M.S., HUANG T.J., et al.: Sexual dimorphic metabolic alterations in hepatitis $C$ Virus-infected patients: A communitybased study in a hepatitis $\mathrm{B} /$ hepatitis $\mathrm{C}$ Virus hyperendemic area. Medicine (Baltimore), 95: e3546, 2016.

6- CHANG M.L., TSOU Y.K., HU T.H., LIN C.H., LIN W.R., SUNG C.M., et al.: Distinct patterns of the lipid alterations between genotype 1 and 2 chronic hepatitis $\mathrm{C}$ patients after viral clearance. PLOS ONE, 9: e104783, 2014.

7- ADOLPH T.E., GRANDER C., GRABHERR F. and TILG H.: Adipokines and non-alcoholic fatty liver disease: Multiple Interactions. Int. J. Mol. Sci., 18: 1649, 2017.

8- KUKLA M., MAZUR W., BULDAK R.J. and ZWIRSKAKORCZALA K.: Potential role of leptin, adiponectin and three novel adipokines-visfatin, chemerin and vaspin- in chronic hepatitis. Molecular Medicine, 17 (11): 1397 410, 2011.

9- ROH S.G., SONG S.H., CHOI K.C., KATOH K., WITTAMER V., PARMENTIER M. and SASAKIS S.: Chemerin-a new adipokine that modulates adipogenesis via its own receptor. Biochem. Biophys. Res. Commun., 362 (4): 1013-8, 2007.

10- WITTAMER V., FRANSSEN J.D., VULCANO M., et al.: Specific recruitment of antigen-presenting cells by chemerin, a novel processed ligand from human inflammatory fluids. J. Exp. Med., 198: 977-85, 2003.

11- RAUCCI R., RUSOLO F., SHARMA A., COLONNA G., CASTELLO G. and COSTANTINI S.: Functional and structural features of adipokine family. Cytokine, 61 (1): $1-14,2013$.

12- BOZAOGLU K., BOLTON K., MCMILLAN J., et al.: Chemerin is a novel adipokine associated with obesity and metabolic syndrome. Endocrinology, 148 (10): 468794, 2007.

13- GORALSKI K.B., MCCARTHY T.C., HANNIMAN E.A., et al.: Chemerin, a novel adipokine that regulates adipogenesis and adipocyte metabolism. Journal of Biological Chemistry, 282 (38): 28175-88, 2007.

14- TAKAHASHI M., TAKAHASHI Y., TAKAHASHI K., et al.: Chemerin enhances insulin signaling and potentiates insulin-stimulated glucose uptake in 3T3-L1 adipocytes. FEBS Letters, 582 (5): 573-8, 2008.

15- WANNINGER J., BAUER S., EISINGER K., et al.: Adiponectin upregulates hepatocyte CMKLR1 which is reduced in human fatty liver. Molecular and Cellular Endocrinology, 349 (2): 248-54, 2012.

16- BUECHLER C.: Chemerin in Liver Diseases. Endocrinol. Metab. Synd., 3: 144, 2014.

17- RABE K., LEHRKE M., PARHOFER K.G. and BROEDL U.C.: Adipokines and insulin resistance. Molecular Medicine, 14 (11-12): 741-51, 2008.

18- MORETTA A., MARCENARO E., PAROLINI S., FERLAZZO G. and MORETTA L.: NK cells at the interface between innate and adaptive immunity. Cell Death Differ, 15 (2): 226-33, 2008.

19- AHIMA R.S. and FLIER J.S.: Leptin. Annu. Rev. Physiol., 62: 413-37, 2000.

20- MARRA F. and BERTOLANI C.: Adipokines in liver diseases. Hepatology, 50 (3): 957-69, 2009.

21- ADINOLFI L., GAMBARDELLA M., ANDREANA A., et al.: Steatosis accelerates the progression of liver damage of chronic hepatitis $\mathrm{C}$ patients and correlates with specific HCV genotype and visceral obesity. Hepatology, 33: 135864, 2001. 
22- GIANNINI E., BARRECA T. and TESTA R.: Leptin in non alcoholic steatohepatitis: Is it one of the "hits"? Am. J. Gastroenterol., 96: 2519-20, 2001.

23- UYGUN A., KADAYIFCI A., YESILOVA Z., et al.: Serum leptin levels in patients with non-alcoholic steatohepatitis. Am. J. Gastroenterol., 95: 3584-9, 2000.

24- FANTUZZI G.: Adipose tissue, adipokines, and inflammation. J. Allergy Clin. Immunol., 115: 911-9, 2005.

25- ALFADDA A.A., SALLAM R.M., CHISHTI M.A., MOUSTAFA A.S., FATMA S., ALOMAIM W.S., ALNAAMI M.Y., BASSAS A.F., CHROUSOS G.P. and JO H.: Differential patterns of serum concentration and adipose tissue expression of chemerin in obesity: Adipose depot specificity and gender dimorphism. Mol. Cells, 33: 591-6, 2012.

26- ABDEL-MESSEIH P.L., MANSOUR H.H. and IBRAHIM D.R.: Evaluation of chemerin and leptin in serum of chronic hepatitis C patients. J. Histol. Cell Biol., 1 (1): 8-12, 2018.

27- ANDREA R.M., CRISTINA P., VICTORIA A. and CERCIL A.S.: The role of new adipokines in the pathogenic mechanisms of chronic hepatitis C. Therapeutic Pharmacy and Clinical Toxicology, 3: 151-4, 2012.

28- HICKMAN I.J., CLOUSTON A.D. and MacDONALD G.A.: Effect of weight reduction on liver histology and biochemistry in patients with chronic hepatitis C. Gut, 51: 89-94, 2002.

29- SHINTANI Y., FUJIE H., MIYOSHI H., et al.: Hepatitis $\mathrm{C}$ virus infection and diabetes: Direct involvement of the virus in the development of insulin resistance. Gastroenterology, 126 (3): 840-8, 2004.

30- KAWAGUCHI T., YOSHIDA T., HARADA M., et al.: Hepatitis $C$ virus down-regulates insulin receptor substrates 1 and 2 through upregulation of suppressor of cytokine signaling 3. American Journal of Pathology, 165 (5): 1499-508, 2004.

31- ESLAM M., KAWAGUCHI T., DEL CAMPO J.A., SATA M., KHATTAB M.A. and ROMERO-GOMEZ M.: Use of HOMA-IR in hepatitis C. J. Viral Hepat., 18 (10): 67584, 2011.

32- MAENO T., OKUMURA A., ISHIKAWA T., KATO K., SAKAKIBARA F., SATO K., AYADA M., HOTTA N., TAGAYA T., FUKUZAWA Y. and KAKUMU S. Mechanisms of increased insulin resistance in non-cirrhotic patients with chronic hepatitis $\mathrm{C}$ virus infection. J. Gastroenterol. Hepatol., 18 (12): 1358-63, 2003.

33- STUART A.A.V., SCHIPPER H.S., TASDELEN I., EGAN D.A., PRAKKEN B.J., KALKHOVEN E. and DE JAGER W.: Altered plasma adipokine levels and in vitro adipocyte differentiation in pediatric type 1 diabetes. J. Clin. Endocrinol. Metabolism., 97 (2): 463-72, 2012.

34- LIAW Y.L.: Role of HCV in dual and triple hepatitis virus infection. Hepatology, 22: 1101-8, 1995.

35- CHEN T.M., HUANG P.T., TSAI M.H., LIN L.F., LIU C.C., HO K.S., SIAUW C.P., CHAO P.L. and TUNG J.N.: Predictors of alpha-fetoprotein elevation in patients with chronic hepatitis $\mathrm{C}$, but not hepatocellular carcinoma, and its normalization after pegylated interferon alfa $2 \mathrm{a}-$ ribavirin combination therapy. J. Gastroenterol. Hepatol., 22 (5): 669-75, 2007.
36- EMOKPAE M.A., ADEJUMOL B.G., ABDU A. and SADIQ N.M.: Serum alpha-fetoprotein level is higher in hepatitis $\mathrm{C}$ than hepatitis $\mathrm{B}$ infected chronic liver disease patients. Niger. Med. J., 54 (6): 426-9, 2013.

37- ARRIETA O., CACHO B., MORALES-ESPINOSA D., RUELAS-VILLAVICENCIO A. and FLORES-ESTRADA D.: The progressive elevation of AFP for the diagnosis of hepatocellular carcinoma in patients with liver cirrhosis. BMC Cancer, 7 (28): 1471-2407, 2007.

38- GHANY M.G., STRADER D.B., THOMAS D.L. and SEEFF L.B.: Diagnosis, management, and treatment of hepatitis C: An update. Hepatology, 49: 1335-74, 2009.

39- FUJITA K., OURA K., YONEYAMA H., SHI T., TAKUMA K., NAKAHARA M., TADOKORO T., NOMURA T., MORISHITA A., TSUTSUI K., HIMOTO T. and MASAKI T.: Albumin-bilirubin score indicates liver fibrosis staging and prognosis in patients with chronic hepatitis C. Hepatol. Res., 49 (7): 731-42, 2019.

40- PARANAGUÁ-VEZOZZO D.C., ANDRADE A., MAZO D.F., NUNES V., GUEDES A.L., RAGAZZO T.G., MOUTINHO R., NACIF L.S., ONO S.K., ALVES V.A. and CARRILHO F.J.: Concordance of non-invasive mechanical and serum tests for liver fibrosis evaluation in chronic hepatitis C. World J. Hepatol., 19 (8): 436-42, 2017.

41- SELL H., DIVOUX A., POITOU C., BASDEVANT A., BOUILLOT J.L., BEDOSSA P., TORDJMAN J., ECKEL J. and CLÉMENT K.: Chemerin correlates with markers for fatty liver in morbidly obese patients and strongly decreases after weight loss induced by bariatric surgery. J. Clin. Endocrinol. Metab., 95: 2892-6, 2010.

42- KUKLA M., ZWIRSKA-KORCZALA K., HARTLEB M., et al.: Serum chemerin and vaspin in non-alcoholic fatty liver disease. Scandinavian Journal of Gastroenterology, 45 (2): 235-42, 2010.

43- YILMAZ Y., YONAL O., KURT R., et al.: Serum levels of omentin, chemerin and adipsin in patients with biopsyproven nonalcoholic fatty liver disease. Scandinavian Journal of Gastroenterology, 46 (1): 91-7, 2011.

44- ERNST M.C., ISSA M., GORALSKI K.B. and SINAL C.J.: Chemerin exacerbates glucose intolerance in mouse models of obesity and diabetes. Endocrinology, 151 (5): 1998-2007, 2010.

45- BOZAOGLU K., SEGAL D., SHIELDS K.A., et al.: Chemerin is associated with metabolic syndrome phenotypes in a Mexican-American population. Journal of Clinical Endocrinology and Metabolism, 94 (8): 3085-8, 2009.

46- TAKAHASHI M., INOMATA S., OKIMURA Y., IGUCHI G., FUKUOKA H., MIYAKE K., KOGA D., AKAMATSU S., KASUGA M. and TAKAHASHI Y.: Decreased serum chemerin levels in male Japanese patients with type 2 diabetes: Sex dimorphism. Endocr. J., 60: 37-44, 2013.

47- ERIKSSON J.G., VENOJARVI M. and OSMOND C.: Prenatal and childhood growth, chemerin concentrations, and metabolic health in adult life. International Journal of Endocrinology, 2016: Article ID 3838646, 6 pages, 2016.

48- IBRAHIM D.R., TAHA M.E. and KAMAL A.M.: Evaluation of adipokine chemerin in hypertensive obese. Biosci. J., 35 (6): 1958-67, 2019. 
49- YAMAWAKI H.: Vascular effects of novel adipocytokines: Focus on vascular contractility and inflammatory responses. Biol. Pharm. Bull., 34: 307-10, 2011.

50- HOO H.J., CHOI H.Y., YANG S.J., KIM H.Y., SEO J.A., KIM S.G., KIM N.H., CHOI K.M., CHOI D.S. and BAIK S.H.: Circulating chemerin level is independently correlated with arterial stiffness. J. Atheroscler. Thromb., 19: 59-66, 2012.

51- TIFTIKCI A., ATUG O., YILMAZ Y., EREN F., OZDEMIR F.T., YAPALI S., et al.: Serum levels of adipokines in patients with chronic HCV infection: Relationship with steatosis and fibrosis. Arch. Med. Res., 40 (4): 294-302, 2009.

52- MARRA F.: Leptin and liver tissue repair: Rodent models provide the answers? J. Hepatol., 46: 12-8, 2007.

53- MOUSA N., ABDEL-RAZIK A., SHETA T., SHABANA W., ZAKARIA S., AWAD M., ABDELSALAM M., ELWAKEEL N., ELKASHEF W., EFFAT N., ELGAMAL A., DEIAB A.G. and ELDARS W.: Serum leptin and homeostasis model assessment-IR as novel predictors of early liver fibrosis in chronic hepatitis B virus infection. Br. J. Biomed. Sci., 75 (4): 192-6, 2018.
54- RAFIQUE N. and AFZAL M.N.: Relationship of serum leptin levels with body mass index and gender. RMJ., 34 (2): 164-6, 2009.

55- NASRI H.: Association of serum leptin levels with various biochemical parameters of bone turnover in maintainance of hemodialysis patients. Pak. J. Nutri., 5: 180-4, 2006.

56- HARITHY R.N.: Relationship of leptin concentration to gender, body mass index and age in Saudi adults. Saudi. Med. J., 25: 1086-90, 2004.

57- HELLSTRÖM L., WAHRENBERG H., HRUSKA K., REYNISDOTTIR S. and ARNER P.: Mechanisms behind gender differences in circulating leptin levels. J. Intern. Med., 247 (4): 457-62, 2000.

58- SAVOURET J.F., RAUCH M. and REDEUILH G.: Interplay between estrogens, progestins, retinoic acid and AP1 on a single regulatory site in the progesterone receptor gene. J. Biol. Chem., 269: 28955-62, 1994.

59- ROLF C., VON E.S., KOKEN U. and NIESCHALG E.: Testosterone substitution of hypogonadal men prevents the age dependant increase in the body mass index, body fat and leptin in healthy aging men. Eur. J. Endocrinol., 146: 505-11, 2002.

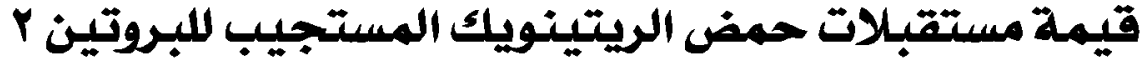 فى المصل كعلامة للتكهن بتطور حالة مرضى إلتهاب الكبد المزمن بفيروس سلى لئى}

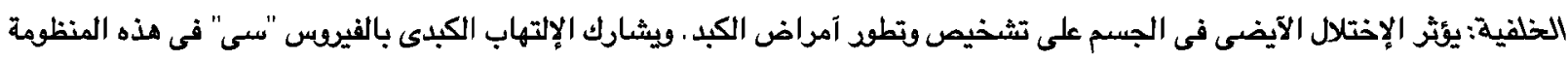

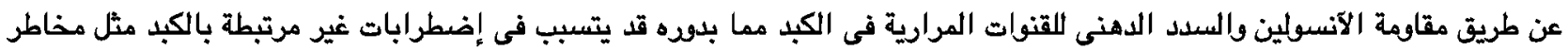

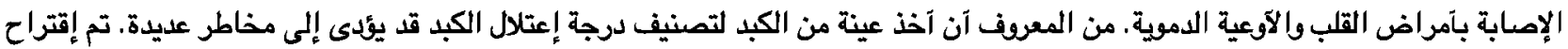

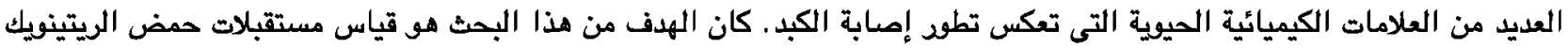

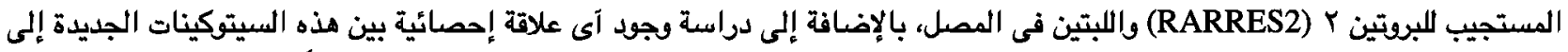

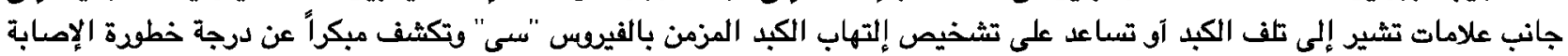
بآمراض القلب والآوعية الدموية.

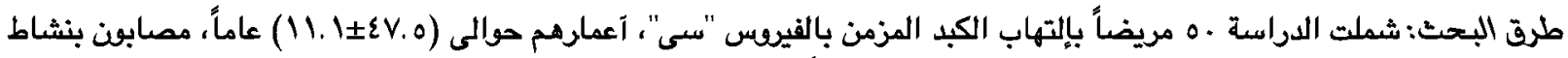

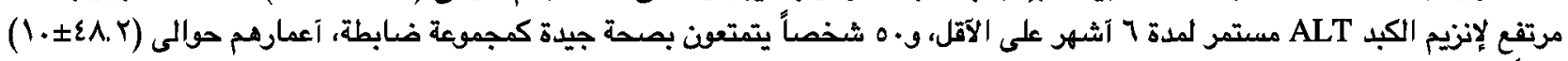

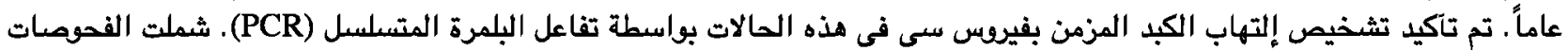

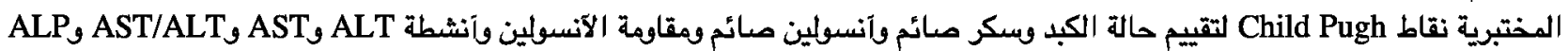

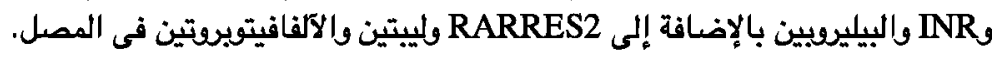

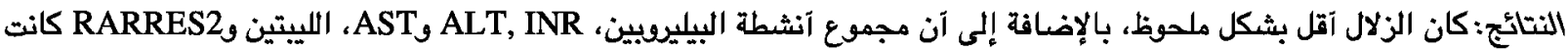

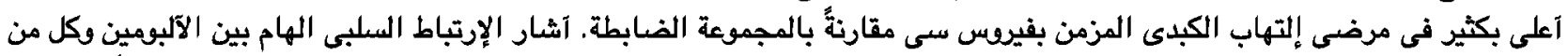

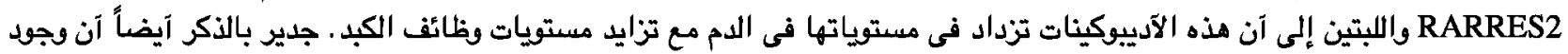

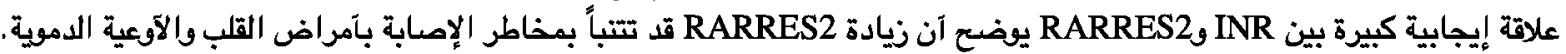

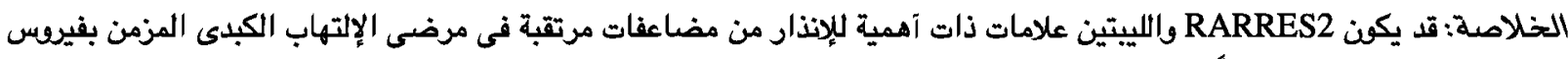

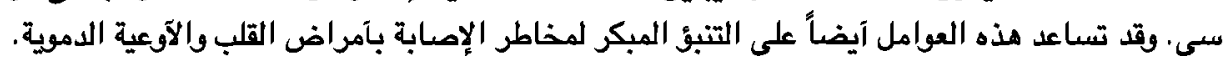

